\title{
Practice of Dramatic Performance in Barka Dance
}

\author{
Durga Lal K. C. \\ Lecturer : English Department \\ NSU, Janata Campus Bijauri, Dang, Nepal \\ Email : durgalalkc@gmail.com
}

(Abstract : Barka dance is one of the greatest dramatic performances of Tharu Culture. This traditional Tharu dance is performed to keep locals safe from danger and diseases. Barka, which literally translates to 'big' in the Tharu language is based on the tales of the Mahabharata and Tharu Lok Mahabharat, Barkimar. The dance, which is carried out from the day of Krishna Janmasthami to Tihar is performed after a long cultural and religious procedure. Though condensed versions of this dance are frequently performed during different festivals and fairs. The complete dance requires worshipping different gods and goddesses. They need more than 30 artists to perform the Barka dance. Every character performs a different role according to the story of Mahabharata. They tell the whole story through songs and performance of the characters. It is very important to perform drama in Barka dance for the Tharu community. They learn the message of the story easily watching the performance rather than telling the story. So it is a very traditional practice in the Tharu community. This dance is at risk of extinction because of its time, cost and lack of artists.)

Key Words : Barka dance, Drama, Barkimar, Mahabharat, performance, Tharu, Culture, epic.

\section{Introduction}

Barka dance and Tharu community are inter connected. They have great attachment with the characters of Mahabharata. So they worship Bhima in most of the festivals. They are in favor of Pandavas. They are singing the songs and performing drama about Mahabharata. They sing the songs collected in Barkimar, the Tharu Lok Mahabharata.

Tharu is the ethnic community of western Terai of Nepal. Most of theTharu people depend on farming. They have ploughed the land for centuries. That's why they are called the sons of Land. Terai is taken as the basket of grain. This basket was filled by Tharu farmers for ages. So they worship the land and many gods related to farming and harvesting. Barka dance is also performed from Krishna Janmasthami to Tihar. This is the time of farming and harvesting paddy. 
There is a belief that this dance promotes good harvest and cures illnesses. Tharu has their own language and culture which make their different identity. Most of the cultures of Tharu community is performed as a drama. Their cultural performance is dramatic.

Some of the songs and dances are related to the great epic like Mahabharata and Ramayana. Artists wear the masks of different characters of the epic and perform it. Some of the songs and dances are related to folk tales. These are also performed as a drama. Most of the Tharu dances are acted out as a drama. The Tharu community started to perform the drama to tell the stories of great epics and folk tales.

Drama is the most effective medium to deliver message to the illiterate people. So, drama became a culture within the culture. So it is very important to study the relationship of drama and its impact on Tharu culture. Many people heavily migrated to the Terai from hilly areas after the eradication of Malaria. Tharu people were displaced from their settlement. They were unable to buy the land. They were just cultivating the land of landlords. Some of the Tharus displaced from Dang and made a settlement in Banke, Bardiya, Kailali and Kanchanpur districts of Nepal.

Tharu community has a combined family tradition. New generation gets knowledge from senior citizens in the family. Generally, old people tell folk tales and its connection with the Tharu community. In the village, there is one leader whom they call 'Mahatawa', 'Ghardhuriya', or 'Balabhansa'. He leads every festivals and worships the 'Bhuiyar Thaan', the most important religious spot in the village. So Barka Dance is related to this tradition.

Barkimar, Tharu Mahabharat was composed on the hearing tradition. According to Ashok Tharu, an expert of Tharu culture, Barkimar is the Tharu folk literature which was prepared on the tradition of hearing and handed over to the generations. Five Pandavas are the main characters of Barkimar. They are performed as a drama in Barka dance. So it becomes easy to understand the story of Barkimar. Dramatic performance is a long practice in Tharu community to convey the message about anything. So dramatic performance in Barka dance is also the traditional practice.

Barka dance is the big dance of Tharu community. It is attached with the history, culture, religious beliefs, farming and tradition of Tharu community. This dance is based on Barkimar, Tharu Mahabharat. Its story is acted out through dramatic performance. This dance needs so many artists, time and cost. So, this dance is not performed regularly. There is gap of 30 years in the performance of this dance. It is very difficult to see this dance when we need it. So this dance is in the risk of declining. So it is very important to study about Barka dance, its functions, its process, dramatic performance, importance of dramactic practice in the dance and findout the reasons 
for declining. This study will help to conserve the Barka dance and make the dramatic practice alive.

It is very difficult to find out the written documents about Tharu culture. Most of the cultural knowledge is limited within the old people. New generation is not ready to hear the stories and document it as a book. We find very few documents about Barka dance.

Ashok Tharu is one of the writers to study and write about Tharu culture. He has collected and written about Barka Dance. He collected the stories and songs from old people and compiled in a book Barkimar. This is the original text for Tharu community to perform Barka dance. Artists perform the Barka dance on the basis of this book.

'The ideal characters of Barkimar, the Tharu folk literature, Panadavas have got the space of Bhuiyar gods. They are worshipped in every festivals as the respectable gods.' (Tharu, 2063, p.284).

This research article is limited only on the Barka dance. It will dig out the dramatic performance in Tharu Barka dance. It will not study about other aspects of Tharu community or culture. This article will analyse how Barka dance is performed in dramatic form. It will focus on the dramatic practice in Tharu community and its connection in Barka dance.

\section{Methodology}

This article is based on the observation of Barka dance, study of some printed documents and conversation with the artists of Barka dance. The main methodologies applied in this study are as follows:

\section{a. Observation of Barka dance}

Barka Dance was observed at Ghorahi Sub metropolitan City ward no. 10, Jalaura, Dang in October, 2019. Dramatic performance of Barka Dance was minutely studied. It is a rare opportunity to see Barka Dance.

b. Observation of documentary

The documentary about Barka Dance was observedwhich was prepared by Tharu Welfare Assembly Dang and Ghorahi Sub metropolitan city Dang in 2020.

\section{c. Field study}

Many Tharu scholars and senior citizens were visited to get knowledge about Barka Dance and Tharu culture. 


\section{d. Conversation with the artists}

There was conversation with the artists of Barka Dance. They have provided the detail information about Barka dance and its importance.

\section{e. Review of related articles.}

For the review, so many articles about Barka dance and Tharu culture were taken as reference materials which strengthened the article.

\section{f. Observation of Cultural performances}

Cultural performances of Tharu community was observed which helped to know the culture of Tharus. It has been very fruitful to see the connection of culture with dramatic performance.

\section{Theoretical Framework :}

Dramatic performance is the main issue of study. So dramatic elements are observed and analyzed in detail. Dramatic elements and performance art are the main tools to analyze the article. This article has deeply studied about dramatic performance in Barka dance. The main focus is on how barka dance is dramatic performance. And more feministic theory has also been applied in this research article. Feministic theory is the analysis of gender and equality. It studies about the perspective of us towards women. It includes about how women are treated in the society and whether they are discriminated or not.

Feminism is the belief in social, economic, and political equality of the sexes. (Burkett, 2019). This theory focuses to the all aspects of gender equality. Feminism is the system of ideas and political practices based on the principle that women are human beings equal to men.(Lengermann and Niebrugge (2010), p.223)

Tharu community is female friendly. Most of the head of the families are females in tharu community. Male and female enjoy in domestic works and cultural performances.

Tharu festivals also focus to the women. Sisters are worshipped in Atwari, Astimki and Maghi. Artists of the cultural performances are also male and females. There are not any cultural practices and performances which discriminate the male and females. Barka dance is also gender friendly. Men and Women artists equally participate in Barka dance.

Men and women artists wear traditional dresses for the dance. They sing songs and dance. Men and Women have a group of dancers. Their role and acting are performed according to the story of Barkimar. Worship of Bhuiyar is abit discriminative. While Bhiyar is worshipped in the process of Barka dance, Only male shawmen lead the whole process. Men are the worshippers of the deities. They perform special ceremony to worship Bhuiyar. Bhuiyar is taken as the important god of Tharus. They worship 
crores of gods and deities in this process. They sacrifice many goats, piggery and chickens to worship the gods. Women don't participate in this worshipping ceremony in the front line. They just manage to collect the materials for worship. So, feminism is the suitable theory for this study. It is applicable for the Barka dance.

\section{Analysis and Discussion :}

Tharus are taken as the innocent ethnic group of Terai. They didn't have their own land and property. So they tried to make their settlements beside the jungles. They could have as much land as they could occupy in the jungle. So they were attracted to the southern part of Terai for a new settlement. This type of displacement and isolation led them to develop a distinct language and culture. Tharu farmers lost their traditional land because of their ignorance and financial problem.

'Hilly people were better educated, familiar with the political system and had connections with the government, quickly gained ownership of most of the farmland in Terai.' (History of Tharu (n.d.).

Thousands of Tharu cultivators became bonded laborers (Kamaiya) farming other people's land. Wives became servants (Kamalari) in landlords' kitchens and children worked in others' households. After a long struggle, Nepal was declared Kamaiya Free Country on 17 July, 2000 and Kamalari Free on 27 June, 2013. After this declaration Tharu community became free and returned back to their culture. They knew the history of their displacement. Their culture is not new and imitation of others. It is based on the traditional practices and literature.

'Tharus have deep affiliation with the river, forest and the land. They love fishing in the pond or river with the help of Tapi, Helka, Cheudi and Jal by both male and female gives a glimpse of the art of fishing. Being non vegetarian, Tharus consume Machhi, Sura, Musuwa, Gangta, Sutahi, Ghoghi, with alcohol. They can't stand eating wild mushrooms like Bamti, Phutki, Khitreya which they collect from the forest. Tharus' main occupation is agriculture. They are the cultivators of the fertile land Tarei'. (Koirala, 2009, p.7)

All the studies till now have focused just on the songs of Barka dance. Noone has focused on the dramatic practice and performance in Barka dance. So, this research is focusing on dramatic performance. It will be very useful for the study of Tharu culture and its connection with drama. It will show the importance of dramatic performance in Tharu culture.

Barka dance is taken as the performance art of the Tharu community. It is big dance by its form, cost and management. Local government is also worried about the decline of this dance. So Ghorahi Sub metropolitan city has prepared a documentary about Barka dance and published a book about performance art of Tharu community 
with the support of Tharu welfare Assembly Dang. The book 'Tharu Performance Art of Ghorahi' describes about Barkimar and Barka dance.

'Barka dance is based on Barkimar, Tharu Mahabharat. This dance is about the dramatic acting and performance of the 18 days war of Kuru Chhetra. This dance is very lengthy and complex. So there is an understanding of performing this dance every five years.' (Acharya and Tharu, 2077, p.60)

The Tharu community is rich in culture. Their culture is based in classical literature. So some of the foreign researchers have also studied about Barka dance. Kurt Meyer from Switzerland and Pamela Deuel from California have written a book about Barka dance.

Their book 'Mahabharat: The Tharu Barka Naach' collects the songs of Barka dance. They have not studied about dramatic performance, acting and its importance. They describe it as a devotional puja.

'The Barka Naach is considered to be a devotional puja that will assure a good harvest for the village. The opening and closing puja are mandatory parts of the performance. But the dance songs which make up the body of the Naach are selected from the Mahabharata.' (Kurta and Deuel, 1998, p. 7).

James Laine has reviewed and commented on this book.

'The epic story is full of distinctive regional variations. In this brief retelling of the epic story. The most striking feature is the central role of Bhima, who is praised throughout as the greatest of heroes. The celebration ofBhima makes the text a truly martial epic rather than an epic modified by brahmanic religious concerns, and consequently, neither Aljuna nor Yudhisthira is given prominence. There are charming twists on the story.' (Laine, 1999).

Barka dance is taken as the very important ceremony of Tharu community. It is based on the Tharu Mahabharat, Barkimar. It is the Tharu folk literature. The Barkimar or Big War is performed in the dance. Barkimar and Barka Naach are the Tharu words. Barki means Big and Mar means War in Tharu language. So Barka dance is also taken as the big dance.

Barka Dance is one of the greatest dramatic performances of Tharu Culture. This traditional Tharu dance is performed to keep locals safe from danger and diseases. Barka, which literally translates to 'big' in the Tharu language, is based on the tales of the Mahabharata. The dance, which is carried out from the day of Krishna Janmasthami to Tihar is performed after a long cultural and religious procedure. It is big not only because of its word but rather by its story, songs, artists, performance, time consuming, preparation and importance too. This dance is related to the farming and harvesting of Tharu community. Tharu is taken as the sons of land. 
So, they are closely connected with the farming and related culture. There is a belief that this dance promotes good harvest and cures illnesses, but many people are afraid to perform it because it involves the worshipping of deities.

'Tharu is one of the ethnic groups which is rich in terms of its own folkore, cultural heritage and language. The folk group is also rich in its traditional skill, knowledge and technology. It has its own way of life and beliefs.' (Acharya, Tharu, Khadka and Chaudhary, 2010).

Dramatic performance is the tradition of Tharu community. There are many songs and dances in Tharu community which are performed as a drama. Most of the Tharu songs are sung with dance. Tharu festival songs are related to the festivals like maghi, astimki, Dashain and Tihar. Every festival has different dramatic performances. In Barka dance, many deities need to be worshipped before dancers start their performance. The dancers also have to be attentive of their every step and movement because if not done properly, it is believed that the dance will unveil disaster, locals believe. But if the dancers perform the dance with deep reverence, it is believed that they will gain divination through the dance. If all the steps from following the correct procedural worship, to selecting the song to performing the dance movements aren't properly followed, people believe that the devil may enter the dancer's body and destroy them.

Barka dance is regarded as an interpretation of the Mahabharata, the songs that are sung during the performances are from Barkimar, the Tharu folk literatue and Mahabharat. Barkimar tells the story about bravery of the Pandavas, the five brothers and the main protagonists of the epic. Sons criticize the injustices carried out by the Kauravas. Bhuiyaar puja is completed before Barka dance. Five different animals are offered to the gods in the respect of five Pandavas. The elders and shamans play an important role in the dance. They are the main singers during the performance.

The main shaman also makes rounds, chanting various mantras, to protect people from being attacked by ghosts and spirits during the performance. This song, which consists of advice, lessons and messages, is also sung during Dashain while getting Tika from the village elder and during harvest. Every character performs their acting representing the characters of Barkimar. At least 30 dancers are required to perform Barka dance.

Male and female artists equally participate in the dance. There is no discrimination between male and female in the performance. So, this dance and its performance are very important to be studied. Tharu culture and its performances are so female friendly. Male and female artists sing the song of Barkimar and dance together. There is no domination by males to the females. All are presented with equal value. So this is also the beauty of Barka dance. 
We can see some discrimination in the Bhuiyar worship. Most of the leading worshippers are males in this process. Bhuiyar worship is important in Barka dance. Crores of gods are worshipped at this time. Goats, pigs, chickens are sacrificed for the gods. Women collect the materials for worship but they can't be the leading personalities in worshipping. It seems abit discriminative, otherwise most of the performances of Barka dance are female friendly. Females are respected in the dance.

So, Barka dance is taken as the performance art of Tharu community. Dramatic performance is a long practice in Tharu community. Men and women enjoy together acting and dancing. They try to make them close with the characters of the literary stories. So, they perform the culture as a drama. Another reason for performing the Barka dance in dramatic form is to deliver a message to the illiterate people who are unable to read the Barkimar. The most beautiful part of this dance is gender equality. Tharu men and women perform the dance. Noone feels any discrimination between men and women in this cultural practice.

"We all are equal. We don't' discriminate to women in Barka naach. Women have also the active role in the performance of dance. Male and female artists are needed in the dance. Our culture is open for the gender issue. We respect females in the culture and religious practices." Said Chandra Prakash Chaudhary, leading artist of Barka dance from Ghorahi submetropolitan-10, Jalaura, Dang.

Another artist Bejhlal Chaudhary from Ghorahi-7, Sisahaniya also says that Barka dance has encouraged the women for cultural practices. "Barka dance is a adventurous dance. It take long time. Artists must have patience to continue dance for weeks. Women artists are ready to take the responsibility of performance for long time. It is a kind of empowerment in women. It is seen in the performance of dance. They have the same spirit and confidence as males." He said.

\section{Conclusion}

Barka dance and dramatic performance are inter linked. Barka dance can not be performed without dramatic function. Whole Story of Barkimar, Mahabharat is performed through drama. It takes more than 3 months to perform the complete dance. So it is called Barka or big dance. Its dramatic performance is enjoying, entertaining and educating the audience. Their dramatic performance of dance is the long practice. They want to make the community aware about their culture and folk tales through drama.

Most of the Tharu people are illiterate, so they enjoy dramatic performance rather than studying the book about Mahabharat. It is the very easy and effective way of educating the illiterate people. It gives entertainment and education together. That's why Tharu ancestors adapted dramatic performance in their culture. New generation learned from the old people and continued its performance. 
Participation of Men and women is also very important in Barka dance. Male and female artists participate equally with traditional dresses to perform the dance. It takes long time to complete the dance but also all women artists continue the dance with men. They don't hesitate to dance for weeks. They follow the songs of Barkimar and perform the dance with artistic skills. It shows the gender equality in Tharu culture.

Tharu People realize their real life in performance art. Characters enjoy masking themselves as a character of Mahabharat. Most of the dances are related to folk tales, literature and epics. The folk tales and epics are carried out on the drama with the real time situations. Barka dance is more important among other dances. It is related to folk literature and Tharu community has believe that this dance avoids the bad omen. Their crops can be good because of this dance. So Tharu artists enjoy to perform this dance. So dramatic performance in Tharu community is very important.

\section{Acknowledgement}

I am grateful to all Scholars of Tharu community who provided me the useful informations about Barka dance and its dramatic performance. I am thankful to the leading artists of Barka dance. I respect to all the experts who reviewed my article and genuinely suggested for its betterment. I am grateful to the editor and all editorial team of Haimaprabha for good cooperation and coordination for the publication of article.

\section{References :}

Acharya, G. and Tharu, A. (2077). Tharu Performance Art of Ghorahi. Ghorahi SubMetropolitan City.

Acharya, G, Chaudhary J. K., Khadka, B.B., Tharu, A. (2010). Tharu Folklore and Folklife : A Close Observation (Regmi, B. N., Trans.).

Brunell, Laura; Burkett, Elinor. (2019). Feminism. Encyclopaedia Britannica. https://www. britannica.com/topic/feminism

Chaudhary, K and Boehm, E D. (2008). Tharu Spelling Dictionary. Tulsipur, Dang. Help Society Nepal. History of Tharu (n.d.). Backward Society Education. http://nepalbase.org/history-of-tharu/

Koirala, C. P.(2009). Maghi Naach : A Study on performance and Tharu Culture (M.A. Thesis). Department of English, Tribhuvan University, Nepal. Kurt, M and Deuel, P (Eds). (1998). Mahabharat: Tharu Barka Naach. Himal Books, Kathmandu.

Laine, J. (1999). Book review of 'The Tharu Barka Naach: A Ritual Folk Art Version of the Mahabharata' by Kurt Meyer and Pamela Deuel (Eds.) . HIMALAYA 19(2).

Lengermann, P., Niebrugge, G. (2010). The Concise Encyclopedia of Sociology. John Wiley \& Sons. McDonaugh, C.(n.d.). The Mythology of the Tharu : Aspects of Cultural Identity in Dang, West Nepal. Oxford Polytechnic.

Tharu, A. (2055). Barkimar. Dual Purposes Kathmandu.

Tharu, A. (2014). Tharu Folk Dance : Sakhya and Painya. Dances of Nepal. Nepal Music Centre Trust Kathmandu.

Tharu, A. (2063). History, Art and Philosophy in Tharu Folk Literature. Change Agent's Forum Nepal. 